\title{
Role of Essential Oils in Control of Rhizoctonia Damping-Off in Tomato with Bioactive Monarda Herbage
}

\author{
Kimberly D. Gwinn, Bonnie H. Ownley, Sharon E. Greene, Miranda M. Clark, Chelsea L. Taylor, \\ Tiffany N. Springfield, David J. Trently, James F. Green, A. Reed, and Susan L. Hamilton
}

First, second, third, fourth, fifth, sixth, and seventh authors: Entomology and Plant Pathology Department; eighth author: Chemistry Department; ninth author: Office of Information Technology, Statistical Consulting Center; and tenth author: Plant Sciences Department, University of Tennessee, Knoxville 37996.

Accepted for publication 11 January 2010.

\begin{abstract}
Gwinn, K. D., Ownley, B. H., Greene, S. E., Clark, M. M., Taylor, C. L., Springfield, T. N., Trently, D. J., Green, J. F., Reed, A., and Hamilton, S. L. 2010. Role of essential oils in control of Rhizoctonia damping-off in tomato with bioactive monarda herbage. Phytopathology 100:493-501.

Plants in the genus Monarda produce complex essential oils that contain antifungal compounds. The objectives of this research were to identify selections of monarda that reduce Rhizoctonia damping-off of tomato, and to determine relationships between essential oil composition of 13 monarda herbages (dried and ground leaves) and disease suppression. Herbages were grouped into five chemotypes, based on essential oil composition and effective concentrations for reducing growth by $50 \%$ for Rhizoctonia solani. Replicated and repeated disease control assays were conducted with monarda herbages in greenhouse medium, with or without Rhizoctonia. Percent survival, seedling height, and stem diameter were evaluated at 8 weeks. Survival, seedling height, and stem diameter

in herbage-only treatments were not different from the control (no-herbage, no-pathogen) for most herbage treatments. In the pathogen control (noherbage + Rhizoctonia), seedling survival was $10 \%$ that of the control. In pathogen-infested media, seedling survival ranged from 65 to $80 \%$ for treatments with thymol chemotypes and 55 to $65 \%$ for carvacrol chemotypes. Effective control of Rhizoctonia damping-off was correlated with phenolic monoterpenes; herbages classified as carvacrol chemotypes effectively protected tomato seedlings from Rhizoctonia damping-off disease without phytotoxicity. This study provides evidence that monarda herbages have potential as growing media amendments for control of Rhizoctonia damping-off disease.

Additional keywords: bee-balm, borneol, bornyl acetate, geraniol, limonene, linalool, Monarda clinopodia, Monarda didyma, Monarda fistulosa, myrcene, 1-octen-3-ol, Oswego tea, $\rho$-cymene, $\alpha$-terpinene, thymol, thymoquinone.
\end{abstract}

Essential oils are highly volatile substances synthesized and stored in glandular trichomes of odiferous plants. The term essential oil refers not only to the complex oils isolated from the plant, but also to their constituent compounds. Volatile components of essential oils are lipophilic molecules that volatilize at low temperatures (4).

Culinary and ethnomedicinal uses for members of the tribe Mentheae of the family Laminaceae (mints) (e.g., Mentha, Monarda, Origanum, Rosmarinus, and Thymus) are based on their chemically diverse essential oils; many of the biologically active components of mint essential oils are terpenes $(22,23)$. Quality and quantity of essential oils depend not only on variety of the plant but also on parameters that are difficult to control, e.g., microclimate and symbiotic relationships with microorganisms $(23,26,32)$. Environmentally regulated changes in peppermint (Mentha $\times$ piperita) are complex interactions of biosynthetic enzyme activity and feedback inhibition (32). In mints, symbiotic relationships with microorganisms altered volatile terpenoid composition and concentration; both mycorrhizal infection of menthol mint (Mentha arvensis) (11), and symptomless fungal endophyte infection of peppermint (26) altered terpenoid chemistry.

Mint oils are well-known antifungal treatments that have been developed as natural fungicides. A mixture of mint oil and citric acid commercially available as Fungastop is a broad spectrum fungicide that reduced post-harvest decay of lettuce (24). Rhizoc-

Corresponding author: K. D. Gwinn; E-mail address: kgwinn@utk.edu

doi:10.1094/PHYTO-100-5-0493

(c) 2010 The American Phytopathological Society tonia solani is sensitive to mint oils. Growth of $R$. solani was reduced when grown on culture medium amended with oils of Monarda didyma or when exposed to the vapors in a microatmosphere test (8). When dispersed in fungal culture media, oils from thyme (Thymus vulgaris) (38), Salvia fruticosa (30), and peppermint (Mentha piperita) (38) also reduced growth of $R$. solani. Growth of $R$. solani was completely suppressed by the phenolic monoterpene, carvacrol at a concentration of $100 \mathrm{mg} / \mathrm{ml}$ and by its structural isomer, thymol, at a slightly higher concentration (150 mg/ml) (27). Carvacrol (ca. $500 \mathrm{mg} / \mathrm{ml}$ ) was the major constituent of essential oils collected from Thymbra spicata, a member of the mint family that grows wild in the eastern Mediterranean; oil extracted from Thymbra spicata completely suppressed growth of $R$. solani (27). Fungicidal activity of Thymus vulgaris oils has been correlated with thymol content (38).

Damping-off of seedlings caused by species of Pythium and Rhizoctonia can reduce number and quality of tomato seedlings. Losses due to Pythium myriotylum were reduced when monarda herbage (ground, dried leaves) from some varieties of Monarda didyma, Monarda clinopodia, and Monarda menthifolia were added to greenhouse growing medium at a rate of $10 \%$ ( $\mathrm{vol} / \mathrm{vol})$ $(5,6)$. Thymol was the major essential oil component of 'Croftway Pink', the most effective monarda herbage treatment for reducing losses due to $P$. myriotylum. Although previous studies have identified reduction of growth of $R$. solani in the presence of chemicals produced by species of monarda, there is little research on the use of herbage as the delivery system for control of Rhizoctonia damping-off disease, and no systematic studies on the correlations between herbage chemistry and disease suppres- 
sion, The objectives of this research were the following: (i) to identify selections of Monarda didyma, Monarda fistulosa, and Monarda clinopodia that reduce Rhizoctonia damping-off of tomato, and (ii) to determine the relationships between essential oil composition of the monarda herbages and disease suppression.

\section{MATERIALS AND METHODS}

Monarda herbage. Monarda plants were grown from cuttings obtained from commercial sources (Table 1) and planted in 2000. Leaves were collected from June through August 2006. Herbage treatments were prepared from leaves that were dried, ground to pass a 5-mm mesh Wiley mill screen, and stored in sealed Mason jars (Ball Corporation, Broomfield, $\mathrm{CO}$ ) at room temperature until use. Monarda herbage treatments that were shown previously to reduce disease loss due to $P$. myriotylum (5) were selected for evaluation in this study.

Essential oil composition was determined from gas chromatography-mass spectrometry (GC-MS) analysis. Prior to analysis, herbage samples were ground to a fine powder in liquid nitrogen; aliquots $(0.5 \mathrm{~g})$ were shaken in $5 \mathrm{ml}$ of hexane for $24 \mathrm{~h}$ at room temperature. Extracts were filtered with a $0.45-\mu \mathrm{m}$ Acrodisc (Pall Life Sciences, Ann Arbor, MI) to remove particulates. Aliquots $(1 \mu \mathrm{l})$ of extracts were introduced with an automatic sample injector (Model 7683, Agilent Technologies, Palo Alto, CA) into an Agilent 6850 series GC system with a quadruple MS Detector (Model 5973) coupled through an HP-5MS column (30-m long, 0.25 -mm internal diameter, $0.25-\mu \mathrm{m}$ film thickness; J\&W Scientific, Agilent Technologies). The starting temperature of $60^{\circ} \mathrm{C}$ was held for $1 \mathrm{~min}$ and then increased by $4^{\circ} \mathrm{C}$ every min until $90^{\circ} \mathrm{C}$ was reached. After $3 \mathrm{~min}$ at $90^{\circ} \mathrm{C}$, the temperature was increased by $2^{\circ} \mathrm{C}$ per min up to $121^{\circ} \mathrm{C}$. The temperature was held for 2 min at $121^{\circ} \mathrm{C}$, followed by a third increase of $6^{\circ} \mathrm{C}$ per min until the temperature reached $182^{\circ} \mathrm{C}$. The final temperature was held for 1 min to complete the program. Identity and concentration of components were confirmed by comparison to standards.

GC-MS analyses of three herbage selections ('Puerto Purification', 'Cerise', and 'Violet Queen') were conducted four times, and analyses of the remaining herbage selections were performed six times. For each herbage, the concentration of each essential oil constituent was calculated by comparison with essential oil standard curves. The arithmetic mean and standard error were calculated for each component. The percentage of the total amount of compound in the extract was calculated from the means.

Essential oils and growth of $\boldsymbol{R}$. solani. Cultures of an isolate of $R$. solani originally isolated from tomato seedlings in Tennessee were maintained on potato dextrose agar (PDA) (Fisher Scientific, Fair Lawn, NJ) at room temperature until use. Essential oil compounds extracted from monarda herbage (Table 2), which were commercially available, were tested for the ability to reduce growth of $R$. solani. All oils were purchased from Sigma-Aldrich
Chemical Co. (St. Louis, MO). Three concentrations of each essential oil were prepared. Undiluted oils were used as the highest concentration; the amount of compound delivered varied from 50 to $65 \mu$ moles/dish (Table 3 ). For lower concentrations, solutions of standardized molarity $(0.5$ and $0.05 \mathrm{M})$ were prepared, resulting in final doses of 5.0 or $0.5 \mu \mathrm{moles} / \mathrm{dish}$, respectively. For essential oil compounds that were solids at room temperature (borneol, thymol, and thymoquinone), the high dose was 5.0 M (50 $\mu$ moles/dish). The volume of air space above the PDA was approximately $4.5 \times 10^{-6} \mathrm{~m}^{3}$, resulting in an approximate concentration of 1.1 to $1.4 \mu \mathrm{moles} / \mathrm{ml}$ (high dose), $0.11 \mu \mathrm{moles} / \mathrm{ml}$ (medium dose), and $0.011 \mu$ moles $/ \mathrm{ml}$ (low dose).

The impact of volatiles on growth of $R$. solani in vitro was measured in microatmosphere tests $(2,17)$. Mycelial plugs of $R$. solani were placed on PDA (1 plug/plate) and a 10- $\mu$ l aliquot of oil was placed on Whatman No. 1 filter paper $(90 \mathrm{~mm})$ in each dish except the controls (Fisher Scientific) in the lid of a petri plate. The plate was inverted, sealed with Parafilm and incubated at room temperature for 3 days. Following incubation, the colony radius of $R$. solani was determined as the mean of three measurements per plate. Mean values were used in the analysis. Fungal growth was calculated as relative growth, based on a value of 1.0 for the control, which contained no essential oils. In order to transform data, values above 1.0 were adjusted to 1.0. Data were transformed (arcsine) prior to analysis.

The experiment was designed as a factorial with 13 essential oils and three concentrations of each oil (undiluted, 5 umoles/ dish, or $0.5 \mu$ moles/dish) in a randomized complete block. Three plates were used for each run, and the experiment was repeated three times for a total of nine replicates. Data from the three runs were pooled and essential oil concentrations were analyzed for significance using a randomized block design analysis of variance (ANOVA) (PROC MIXED procedure of SAS, version 9.1.3, SAS Institute, Cary, NC). Replications were considered random in the mixed model. Significant effects were further analyzed with an $F$ protected least significant difference (LSD) $(P=0.05)$. Means were used to calculate the concentration at which growth is reduced by $50 \%$ the effective concentration $\left(\mathrm{EC}_{50}\right) . \mathrm{EC}_{50}$ values were determined by linear regression (SigmaPlot 9.0, Systat Software, Chicago, IL).

Chemotypes. Hierarchical agglomerative cluster analysis (SPSS Statistics for Window Version 15, SPSS Inc., Chicago, IL) was used to organize monarda varieties into meaningful subgroups, termed chemotypes, having similar component oil characteristics. Concentrations of oils were multiplied by the inverse of the $\mathrm{EC}_{50}$. Data were transformed to $\mathrm{Z}$-scores, and squared Euclidean distance was used as the similarity criterion for clusters. A five cluster solution, obtained using Ward's minimum variance method, was selected for further analysis $(7,36,37)$.

Disease control assays. $R$. solani was grown on PDA for 7 days at room temperature. Plates were flooded with $6 \mathrm{ml}$ of

TABLE 1. Scientific names and sources of Monarda selections used in this study

\begin{tabular}{llll}
\hline Scientific name & Cultivar & \multicolumn{1}{c}{ Source } & Chemotype \\
\hline Monarda clinopodia & - & Native Gardens Nursery, Greenback, TN 37742 & Thymol \\
Monarda didyma & Cerise & Cedar Springs Nursery, Zirconia, NC 28790 & Borneol \\
& Croftway Pink & Sunny Border Nurseries, Kensington, CT 06037 & Thymol \\
& Lavender & Sandy Mush Herb Nursery, Leicester, NC 28748 & Carvacrol \\
& Prairie Night & Martin Viette Nurseries, East Norwich, NY 11732 & Borneol \\
Monarda fistulosa & Violet Queen & Sunny Border Nurseries, Kensington, CT 06037 & Carvacrol \\
Monarda fistulosa $\times$ didyma & Mahogany & Sunny Border Nurseries, Kensington, CT 06037 & Thymol \\
Monarda sp. & Trinity Purple & Sandy Mush Herb Nursery, Leicester, NC 28748 & Trinity Purple \\
Monarda sp. (hybrid?) & Puerto Purification & Sunny Border Nurseries, Kensington, CT 06037 & Thymol \\
& Mohawk & Heronswood Nursery, Kingston, WA 98346 & Thymol \\
& Rose Geranium & Nichols Garden Nursery, Albany, Oregon 97321 & Geraniol \\
& Rose-scented & Richters, Goodwood, Ontario, Canada L0C 1A0 & Geraniol \\
\hline
\end{tabular}

${ }^{\mathrm{z}}$ Producer identified these only by cultivar name. Many commonly grown cultivars of Monarda are hybrids of Monarda didyma and Monarda fistulosa (12). 
sterile deionized water, and mycelia were collected by scraping the culture surface. The mycelial suspension was poured into a 500-ml flask containing sterile 3\% cornmeal: sand (309 g). Plates were flooded a second time with $10 \mathrm{ml}$ of sterile deionized water. The suspension was added to the mixture, and inoculum was incubated at room temperature for 12 days.

Monarda herbage, prepared as described above, was mixed at $10 \%$ (vol/vol) into BM-2 (Berger Peat Moss, Inc., St. Modeste, Quebec, Canada) greenhouse growing medium, with or without addition of Rhizoctonia inoculum (4\%, wt/wt). Controls were BM-2 alone (no herbage + no pathogen control) or BM-2 with Rhizoctonia inoculum (no herbage + pathogen control). The mixtures were placed in greenhouse trays with $47-\mathrm{mm}$ diameter cells, and two tomato seeds (cv. Mountain Spring) were planted per cell. Each cell constituted one replicate with two subsamples (seeds).

The experiment was designed as a $14 \times 2$ (herbage $\times$ pathogen) factorial with five replicates. Percent survival of plants, seedling height, and stem diameter at the cotyledonary scar were evaluated at 8 weeks after seeding. The experiment was repeated once. The block-treatment interactions were not significantly different based on Tukey's single degree of freedom test; therefore, the data were pooled for analysis. Main effects of herbage and pathogen, and the interaction were analyzed for significance using a randomized block design ANOVA (PROC MIXED procedure of SAS). Replication was considered random in the mixed model. Significant effects were further analyzed with Fisher's protected LSD at $P=0.05$. Residuals for the variable percent survival were normally distributed; therefore, an arcsine transformation was not applied prior to analysis.

Chemotype differences among variables. Monarda herbages were classified by chemotype based on cluster analysis as described previously, and the mean differences in percent survival, seedling height, and stem diameter, between plants in herbage alone and plants in the herbage + pathogen treatment were calculated for each chemotype. The effect of chemotype on shoot height and stem diameter in herbage alone treatments was analyzed for significance using ANOVA (SPSS Inc.). The effect of chemotype on the mean difference variables for percent survival, seedling height and stem diameter was analyzed for significance with the PROC MIXED procedure of SAS; significant effects were further analyzed with the $F$-protected LSD at
$P=0.05$. To determine if the mean difference variables were different fronm zero by chemotype, a $t$ test $(P=0.05)$ on least square means was employed.

\section{RESULTS}

Herbage chemistry and chemotypes. Hexane extracts of Monarda selections differed in the composition of essential oils (Table 2). Most extracts contained several types of terpenes (Fig. 1), but were organized into five chemotypes based on hierarchical agglomerative cluster analysis (Table 2). The fifth cluster (TP) was not included in analyses of cluster differences because it had a sole member, 'Trinity Purple', a selection that primarily contained cymene (a terpenic hydrocarbon). When the remaining four

TABLE 3. Calculated essential oil at $50 \%$ effective concentration $\left(\mathrm{EC}_{50}\right)$ for Rhizoctonia solani based on relative growth in microatmosphere test

\begin{tabular}{llcc}
\hline Essential oil & Functional group & $\begin{array}{c}\text { No. of moles } \\
\text { in undiluted } \\
\text { treatment }^{\mathrm{y}}\end{array}$ & $\begin{array}{c}\text { Calculated EC }_{50} \\
(\mu \text { moles/dish) }\end{array}$ \\
\hline Thymol & Phenolic & 50.0 & 37.05 \\
1-Octen-3-ol & $\begin{array}{l}\text { Alcohol } \\
\text { (allylic-secondary) }\end{array}$ & 65.3 & 39.62 \\
Carvacrol & Phenolic & 65.0 & 43.80 \\
Linalool & Alcohol (tertiary) & 58.3 & 50.45 \\
Bornyl acetate & Ester & 50.0 & 56.75 \\
$\alpha$-Terpineol & Alcohol (tertiary) & 60.5 & 88.69 \\
Geraniol & Alcohol & & 119.42 \\
$\beta$-Pinene & None & 57.7 & 168.38 \\
Thymoquinone & None & 63.9 & 174.57 \\
$\gamma$-Terpinene & None & 50.0 & 175.04 \\
Borneol & Alcohol (secondary) & 62.3 & 187.36 \\
Cineole & Ether & 50.0 & 199.52 \\
Cymene & None & 59.7 & 249.05 \\
Limonene & None & 64.1 & 818.67 \\
Myrcene & None & 61.9 & 965.17 \\
$\alpha-P i n e n e$ & None & 58.4 & $>1,000$ \\
\hline
\end{tabular}

y Molecular mass was rounded to the nearest integer. Data were obtained from Sigma Aldrich. Undiluted treatment was based on a 10- $\mu$ l drop of oil. Thymol, thymoquinone, and borneol are solids at room temperature, therefore, 50.0 moles was the highest concentration evaluated.

${ }^{\mathrm{z}}$ Derived from regression analysis of data presented in Figure 2.

TABLE 2. Chemotype and essential oil profile of 12 Monarda didyma cultivars and one selection of Monarda clinopodia used in this study

\begin{tabular}{|c|c|c|c|c|c|c|c|c|c|c|c|c|c|}
\hline \multirow[b]{2}{*}{ Essential oil ${ }^{\mathrm{x}}$} & \multicolumn{5}{|c|}{ Thymol $^{\mathrm{y}}$} & \multicolumn{2}{|c|}{ Carvacrol } & \multicolumn{2}{|c|}{ Geraniol } & \multicolumn{3}{|c|}{ Borneol } & \multirow{2}{*}{$\begin{array}{l}\text { Trinity } \\
\text { Purple } \\
\text { Trinity } \\
\text { Purple }\end{array}$} \\
\hline & $\begin{array}{c}\text { Puerto } \\
\text { Purification }\end{array}$ & $\begin{array}{c}\text { Monarda } \\
\text { clinopodia }\end{array}$ & Mohawk & Mahogany & $\begin{array}{l}\text { Croftway } \\
\text { Pink }\end{array}$ & Lavender & $\begin{array}{l}\text { Violet } \\
\text { Queen }\end{array}$ & $\begin{array}{c}\text { Rose } \\
\text { Geranium }\end{array}$ & $\begin{array}{l}\text { Rose- } \\
\text { scented }\end{array}$ & $\begin{array}{l}\text { Prairie } \\
\text { Night }\end{array}$ & $\begin{array}{l}\text { Mixed } \\
\text { Purple }\end{array}$ & Cerise & \\
\hline Thymoquinone & 49.34 & 51.64 & 44.43 & 5.86 & 12.75 & 5.34 & 21.33 & 0.00 & 0.00 & 22.25 & 25.06 & 10.14 & 0.02 \\
\hline Carvacrol & 3.67 & 5.135 & 0.08 & 6.75 & 1.21 & 69.71 & 46.78 & 0.00 & 0.00 & 0.03 & 1.53 & 0.36 & 0.06 \\
\hline Thymol & 23.68 & 22.59 & 7.60 & 72.87 & 38.01 & 0.02 & 0.01 & 0.00 & 0.00 & 5.51 & 12.85 & 12.27 & 0.36 \\
\hline 1-Octen-3-ol & 0.97 & 6.50 & 4.93 & 0.80 & 2.43 & 3.48 & 7.14 & 8.39 & 4.21 & 9.79 & 6.94 & 21.68 & 0.06 \\
\hline Geraniol & 0.00 & 0.00 & 0.00 & 0.00 & 0.00 & 0.00 & 0.00 & 88.16 & 93.90 & 0.06 & 0.00 & 0.00 & 0.00 \\
\hline Linalool & 0.04 & 0.44 & 0.46 & 0.00 & 0.42 & 0.00 & 0.11 & 1.27 & 0.48 & 29.29 & 34.75 & 0.58 & 0.02 \\
\hline Borneol & 0.13 & 0.00 & 0.00 & 0.00 & 0.00 & 0.02 & 0.00 & 0.00 & 0.00 & 0.44 & 2.18 & 11.73 & 0.01 \\
\hline$\rho$-Cymene & 19.71 & 12.00 & 31.78 & 9.22 & 33.92 & 16.99 & 21.17 & 0.00 & 0.00 & 23.72 & 13.09 & 20.11 & 72.18 \\
\hline Myrcene & 0.01 & 0.00 & 0.99 & 0.84 & 1.06 & 0.52 & 0.00 & 2.15 & 1.25 & 0.54 & 0.37 & 2.67 & 1.19 \\
\hline$\alpha$-Terpinene & 0.76 & 0.44 & 1.11 & 0.27 & 1.41 & 0.40 & 0.39 & 0.13 & 0.00 & 0.37 & 0.34 & 6.97 & 0.52 \\
\hline$\gamma$-Terpinene & 0.06 & 0.34 & 7.11 & 2.60 & 6.63 & 1.58 & 1.36 & 0.00 & 0.00 & 0.42 & 0.44 & 6.97 & 24.44 \\
\hline Limonene & 1.00 & 0.44 & 0.76 & 0.60 & 1.32 & 1.12 & 0.84 & 0.00 & 0.00 & 1.44 & 0.54 & 1.37 & 0.73 \\
\hline Total $(\mu \text { moles })^{\mathrm{z}}$ & 45.37 & 7.66 & 2.60 & 6.98 & 35.41 & 6.75 & 13.96 & 6.76 & 9.08 & 1.45 & 2.88 & 8.78 & 9.14 \\
\hline
\end{tabular}

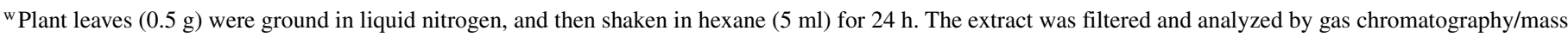
spectrometry. Compounds were identified by comparison of retention time and mass spectrum to National Institute of Standards and Technology library and authentic standards. Concentration was determined from standard curves. Values are the percentage of total oils extracted and are derived from means of six analyses. Monarda didyma, Monarda fistulosa cultivars, or Monarda clinopodia from which herbage was harvested. Values are the relative percentage that each essential oil represents in the herbage extract.

${ }^{x}$ Chemotype designation was based on the primary component of the extract. For each chemotype, unique differences in essential oil components are shaded.

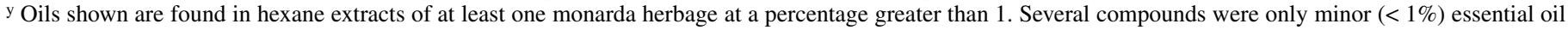
components in all herbage samples tested and included bornyl acetate, camphene, carene, 3 -octanol, $\alpha$-terpineol, and $\alpha$ - and $\beta$-pinene.

${ }^{z}$ Values are the total number of $\mu$ moles of all compounds in hexane extract. 
clusters were compared by chemical components using ANOVA models, cluster 1 differed significantly from clusters 2,3 , and 4 only in thymol content $(P=0.0209)$ and was designated as the thymol chemotype. Members of the thymol chemotype had either thymoquinone or thymol as the primary essential oil extracted by hexane. 'Puerto Purification', Monarda clinopodia, and 'Mohawk' had high proportions of thymoquinone (at least 44\%) and moderate concentrations of thymol; the primary constituent of 'Mahogany' (72\%) and 'Croftway Pink' (38\%) was thymol. The second cluster was significantly different from all other clusters in carvacrol content $(P=0.0001)$; no other chemical components distinguished this cluster from the other four. Extracts from members of the carvacrol chemotype, 'Lavender' or 'Violet Queen', contained at least $45 \%$ carvacrol. The third cluster differed from all other clusters in the proportion of geraniol $(P=$ $0.0041)$ and also differed from the thymol and carvacrol chemotypes in linalool $(P=0.0055)$ proportions in the extracts. Members of the third cluster differed from other clusters in limonene concentrations $(P=0.0439)$; neither herbage contained limonene. The two members of cluster 3, 'Rose Geranium' and 'Rose-scented' extracts, contained primarily geraniol (at least $88 \%$ ); this cluster was termed the geraniol chemotype. Members of the fourth cluster also differed from all other clusters in borneol $(P=0.0101)$ and was termed the borneol chemotype; although levels of borneol detected in 'Prairie Night', 'Cerise', and 'Mixed Purple' were low, no members of another cluster had higher than $0.2 \%$ borneol. Concentrations of, 1-octen-3-ol, $\rho$ cymene, myrcene, $\alpha$-terpinene, and $\gamma$-terpinene were not significantly different among analyzed clusters.

In addition to the compounds in Table 2, several compounds were minor essential oil components in all herbage samples tested. Bornyl acetate was isolated from 'Prairie Night', 'Mixed Purple', 'Cerise', and 'Trinity Purple'. Camphene was extracted<smiles>CC1=CC(=O)C(C(C)C)=CC1=O</smiles>

thymoquinone<smiles>Cc1ccc(C(C)C)cc1O</smiles>

carvacrol phenolic monoterpene

Fig. 1. Minimum energy structures of representative chemicals isolated from monarda herbage. Marvin was used for drawing, displaying, and characterizing chemical structures, substructures, and reactions (Marvin 5.2.1, ChemAxon, Budapest, Hungary). from 'Prairie Night', 'Mixed Purple', 'Cerise', 'Lavender', 'Violet Queen', and 'Puerto Purification'. The essential oil carene was isolated only from Monarda clinopodia and 'Mahogany', while 3-octanol was isolated only from 'Violet Queen', 'Prairie Night', and 'Rose-scented'. 'Cerise' was the only cultivar that contained $\alpha$-terpineol. Both $\alpha$ - and $\beta$-pinene were found in all plants except 'Rose Geranium' and 'Rose-scented'.

Selections of Monarda differed not only in the major component extracted in hexane, but also in the concentration of the components (Table 2). There were no differences among chemotypes for total essential oil; however, within each chemotype, total concentration of essential oil was highly variable. For example, in the thymol chemotypes, total essential oil concentration ranged from $2.6 \mu \mathrm{mole} / \mathrm{ml}$ in 'Mohawk', to $45.37 \mu \mathrm{moles} / \mathrm{ml}$ in 'Puerto Purification'. In the carvacrol chemotypes, 'Violet Queen' had twice the concentration of total essential oils as 'Lavender'. The two members of the geraniol chemotype had similar concentrations of total essential oils. 'Prairie Night' (borneol chemotype) contained the lowest amount of total essential oils of all the Monarda selections.

Impact of essential oils on $\boldsymbol{R}$. solani growth in vitro. The impact of essential oils on growth of $R$. solani in the microatmosphere studies was dependent upon the specific oil compound (Fig. 2; Table 3). All oils with $\mathrm{EC}_{50}$ values of less than $100 \mu$ moles/dish had an oxygen-containing functional group. Thymol and carvacrol (phenolic monoterpenes) reduced growth by more than $65 \%$ when tested at the highest concentration. Reduction of growth by alcohols was variable; growth was reduced by $90 \%$ at the highest concentration of 1-octen-3-ol, a secondary allylic alcohol, but only by $20 \%$ by borneol, which contains a secondary alcohol that is not allylic. Oils that did not have an oxygen-containing functional group either did not inhibit growth of $R$. solani (limonene, myrcene, and $\alpha$-pinene) or reduced growth by less than $20 \%$ ( $\beta$-pinene, thymoquinone, $\gamma$ terpinene, and cymene).

Rhizoctonia damping-off assay. Percent survival of tomato seedlings was significantly different for the main effects of herbage $(P=0.0010)$ and pathogen $(P<0.0001)$, and the herbagepathogen interaction $(P=0.0076)$. In the no-herbage + pathogen control, disease loss due to Rhizoctonia was 90\% (Fig. 3A). All herbage-only treatments, except 'Trinity Purple', were not different from the no-herbage, no-pathogen control. Seedling survival in herbage $+R$. solani was greater than the no-herbage + pathogen control for all herbage treatments except two borneol chemotypes ('Cerise' and 'Mixed Purple'), 'Rose-scented' (geraniol chemotype), and 'Trinity Purple' (Fig. 3A). For all herbages classified as thymol chemotypes, except 'Croftway Pink', percentages of surviving seedlings in the herbage + pathogen treatment were not different from the control with no-herbage and no-pathogen. For each herbage in the thymol and carvacrol chemotypes (except 'Croftway Pink' and 'Violet Queen'), percent survival in herbage + pathogen treatment was not different from that in herbage + no pathogen (Fig. 3A). The least square means estimate for percent survival in pathogen-infested media for thymol chemotypes was $73 \%$. In pathogen-infested media with herbage, percent survival for carvacrol chemotypes averaged $60 \%$.

Seedling height was significantly different for the main effects of herbage $(P=0.0254)$ and pathogen $(P<0.0001)$, and the herbage-pathogen interaction $(P=0.0273)$. None of the herbages affected seedling height in the absence of the pathogen (Fig. 3B). The height of plants in six herbage + pathogen treatments ('Mohawk', 'Mahogany', 'Croftway Pink', 'Lavender', 'Violet Queen', and 'Rose Geranium') was not different from that in the no-herbage, no-pathogen control. For six herbage treatments (Monarda clinopodia, 'Rose-scented', 'Praire Night', 'Mixed Purple', 'Cerise' and 'Trinity Purple'), seedling height was reduced in pathogen-infested medium and was not different from 
that in the no-herbage + pathogen control (Fig. 3B). For each herbage, seedling height was not different with and without addition of pathogen for all thymol chemotypes, except 'Croftway Pink', and both carvacrol chemotypes (Fig. 3B). Stem diameter was significantly different for the main effects of herbage $(P=$ $0.0151)$ and pathogen $(P<0.0001)$, and the herbage-pathogen interaction $(P=0.0076)$. None of the herbages affected stem diameter in the absence of the pathogen (Fig. 3C). Stem diameter of plants in herbage + pathogen was significantly lower for Monarda clinopodia, 'Rose-scented', all four borneol chemotypes, and 'Trinity Purple' than that in the no-pathogen no-herbage control, and did not differ from the no-herbage + pathogen control (Fig. 3C). Only five herbage treatments, 'Puerto Purification', 'Mohawk', 'Mahogany', 'Lavender', and 'Violet Queen', had stem diameters that did not differ with and without addition of $R$. solani (Fig. 3C).

Chemotype differences among variables. When analyzed by chemotype, seedling height was not different from no-herbage controls for all chemotypes $(P<0.1585)$ (Fig. 4A), but stem diameter for thymol chemotypes was different from all other chemotypes and the no-herbage controls $(P<0.0197)$ (Fig. 4B). The effect of chemotype on the mean difference in percent survival between herbage-only and herbage + pathogen treatments was significant $(P=0.0163)$. The difference in percent survival was lower for thymol and carvacrol chemotypes, which did not differ (Fig. 5A). The difference was greater for borneol and geraniol chemotypes; both differed from thymol, but only borneol differed from carvacrol chemotypes. All four chemotypes had positive mean differences that were significantly different from zero (thymol $[P=0.0178]$; carvacrol $[P=0.0289]$; geraniol $[P=0.0004]$; borneol $[P=0.0001])$.

The effect of chemotype was significant $(P=0.0186)$ for mean difference in seedling height between herbage-only and herbage + pathogen treatments. While all four chemotypes had positive mean differences, the difference in seedling height between herbage-only and herbage + pathogen was significantly different from zero for only three: thymol $(P=0.0451)$, geraniol $(P=$ $0.0008)$, and borneol $(P=0.0002)$. The mean difference in herbage only and herbage + pathogen treatments was smaller in thymol than geraniol and borneol chemotypes; differences for carvacrol chemotypes did not differ from the other chemotypes (Fig. 5B).

Stem diameter of seedlings in herbage and herbage + pathogen treatments was different among chemotypes $(P=0.0171)$. Among chemotypes, the mean difference in stem diameter between herbage only and herbage + pathogen treatments differed from zero only for geraniol $(P=0.0009)$ and borneol $(P=0.0003)$ chemotypes. The mean difference in stem diameter for herbage only and herbage $+R$. solani treatments was small for thymol and carvacrol chemotypes and significantly larger for geraniol and borneol chemotypes (Fig. 5C).

\section{DISCUSSION}

The Monarda selections used in this study were Monarda didyma, Monarda fistulosa, Monarda clinopodia, or an unidentified species or hybrids between species. For some selections, a scientific name was not given by the producer, but many commercially available varieties of monarda are hybrids of Monarda didyma and Monarda fistulosa (13). Essential oils collected from Monarda fistulosa and Monarda didyma have been reported to be effective antifungal agents $(8,17)$; in those studies, the primary constituent of the essential oils was either thymoquinone (Monarda fistulosa) (17) or thymol (Monarda didyma) (8). Ethanol extracts of Monarda fistulosa contained thymoquinone and either thymol or carvacrol (19). Hexane extracts were chosen for this

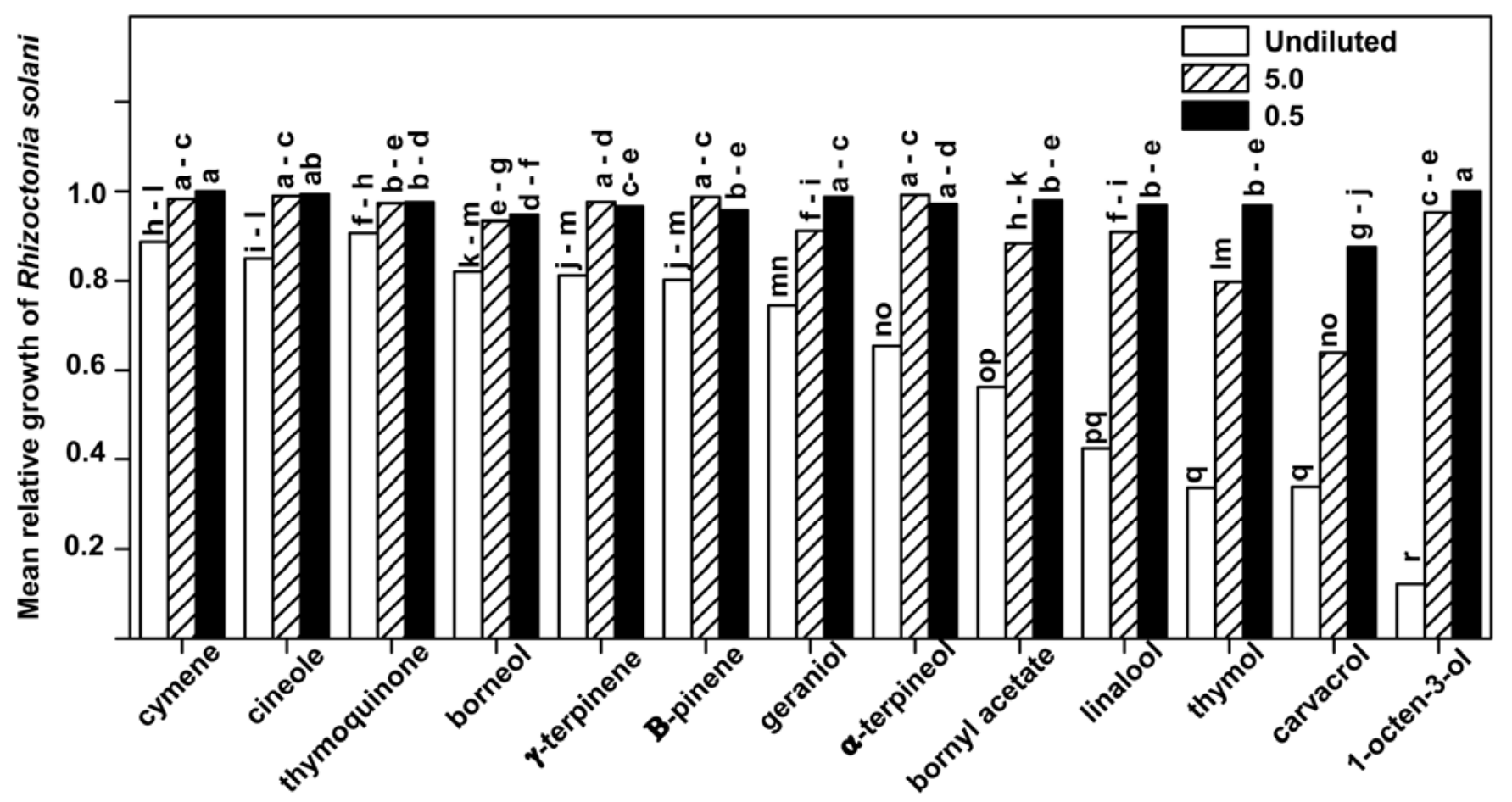

Essential oil

Fig. 2. Impact of selected terpenes on the growth of Rhizoctonia solani in microatmosphere tests. Growth of R. solani on potato dextrose agar was measured after 3 days in the presence of terpenic oils. Fungal growth was calculated as relative growth, based on a value of 1 for the control (without oil). Three dosages of 13 oils undiluted (UD), $5 \mu \mathrm{moles} / \mathrm{dish}$, or $0.5 \mu \mathrm{moles} / \mathrm{dish}$ were tested; experiment was replicated for a total of nine replicates. Data were analyzed for significance with Proc Mixed of PC-SAS version 9.1.3. Values represented by bars are least square means. Bars with the same letter are not significantly different according to an $F$-protected least significant difference at $P=0.05$. 
study for ease of preparation and consistency of the results in multiple subsamples (5). Hexane extracts from the Monarda selections used in this study differed in the amount and type of terpenes (Fig. 1; Table 2) but our results were consistent with those previously reported $(8,17,19,23)$. At least one cultivar identified by the producers as Monarda didyma was placed in each chemotype except the geraniol chemotype; the single representatives of Monarda fistulosa and Monarda clinopodia were classified as thymol chemotypes (Table 1).

Essential oils collected from mints and their terpenic components are well-known antifungal compounds, and impact on the growth of $R$. solani has been demonstrated $(8,15,27,29,38)$.
Carvacrol and thymol were highly active against $R$. solani in this study (Fig. 2; Table 3); in previous studies, oils extracted from Monarda didyma leaves and stems that contained more than $50 \%$ thymol completely suppressed $R$. solani growth (8). Essential oils collected from Orthosiphon stamineus contained primarily sesquiterpenes and monoterpenes (1-octen-3-ol, $\beta$-pinene, and limonene) and reduced growth of $R$. solani by $56 \%$; there was increased inhibition when either methanol extracts of leaves $(70 \%)$ or a hexane extract of the methanol $(63 \%)$ were tested (15). In studies by Angioni et al. (1), essential oils from Lavandula stoechas L. ssp. stoechas leaves or flowers inhibited growth of $R$. solani; myrtenal was the primary component and was the only

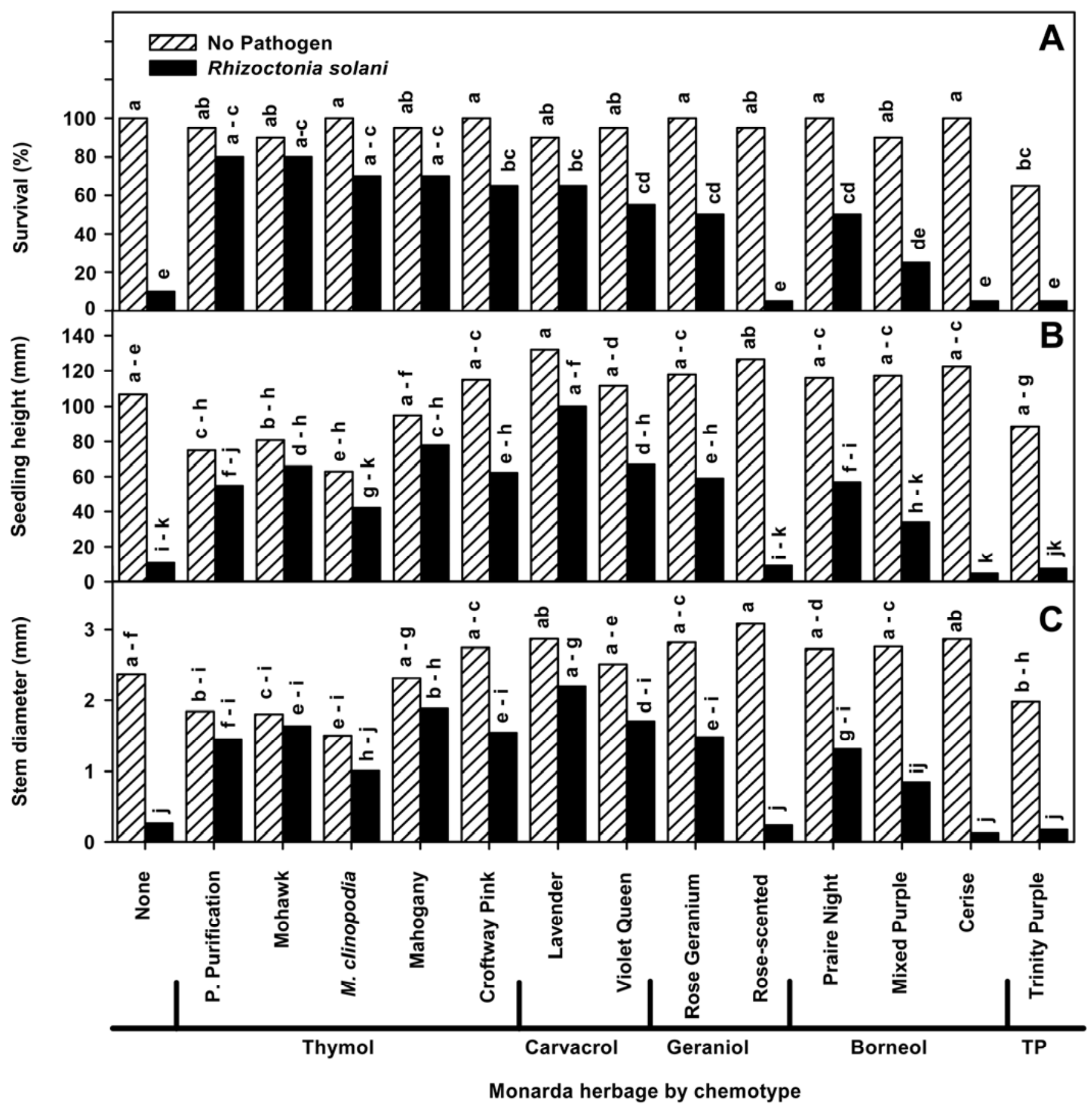

Fig. 3. Impact of monarda herbage on A, survival (\%), B, height ( $\mathrm{mm})$, and $\mathbf{C}$, stem diameter $(\mathrm{mm})$ of tomato seedlings grown in greenhouse mix infested with Rhizoctonia solani. Each replicate consisted of two plants with five replicates for each treatment; experiment was repeated. Seeds were planted in BM-2 or BM-2 amended with one of 13 monarda herbages, both with and without $R$. solani. Data were collected 8 weeks after planting. Values represented by bars are least square means. Bars with the same letter are not significantly different according to an $F$-protected least significant difference at $P=0.05$. Herbages were organized by cluster analysis into chemotypes based on extracted oils. 
component that inhibited growth when the low dose $(20 \mu \mathrm{l})$ was tested (1). At the high dose $(60 \mu \mathrm{l})$, limonene inhibited growth by $100 \%$ and bornyl acetate inhibited growth by $22 \%$. Borneol and $\alpha$-pinene had no effect on $R$. solani growth at the high dose (1). At the highest dose in our laboratory studies, $(10 \mu \mathrm{l}$ of undiluted oil), growth was reduced by $16 \%$ in the presence of borneol and by $44 \%$ in bornyl acetate. Limonene and $\alpha$-pinene were inactive. Differences between our results and those of Angioni et al. (1) may result from the different type of tests (agar disk diffusion versus microatmosphere) or fungal isolate sensitivity. In microatmosphere tests, more citron oil (main constituent is limonene) and lavender oil (main constituent is linalool) accumulated in the mycelium of Aspergillus fumigatus and in the medium on which it was grown than thyme oil (main constituent is carvacrol) (18); significant accumulations occurred within $5 \mathrm{~min}$. The 3 -day-long exposure times used in our studies ensured diffusion into the agar, but the degree of accumulation was different among the chemicals and dependent upon chemical characteristics such as vapor pressure and water solubility (9). Our method, however, mimicked herbage-amended media where $R$. solani was exposed both to volatiles emitting from herbage particles and was in direct contact with the herbage particles.

In laboratory studies, all compounds that reduced growth of $R$. solani by more than $25 \%$ were oxygenated monoterpenes. The low activity or inactivity of the hydrocarbons that we observed is similar to previous work conducted on bacteria and Candida

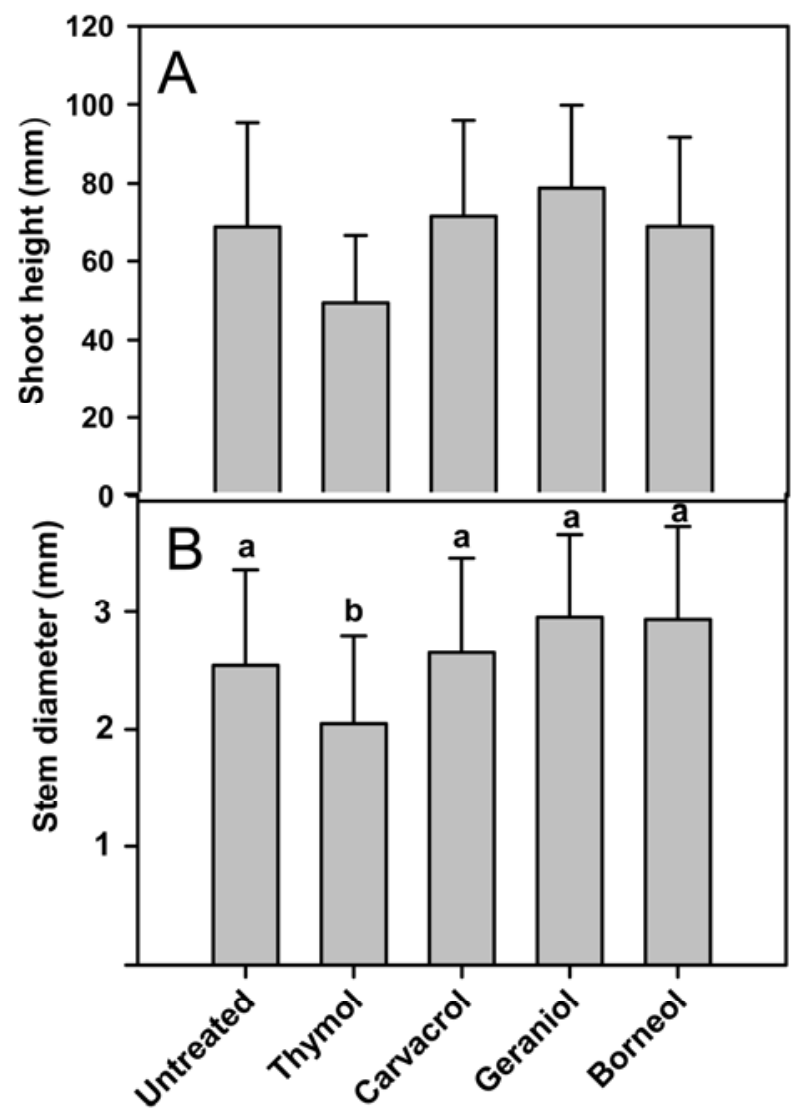

\section{Chemotype}

Fig. 4. Effects of herbage chemotype on $\mathbf{A}$, seedling height ( $\mathrm{mm}$ ), and $\mathbf{B}$, stem diameter $(\mathrm{mm})$. Data were collected 8 weeks after planting. Each replicate consisted of two seeds with five replicates for each treatment; experiment was repeated. Seeds were planted in BM-2 or BM-2 amended with one of 13 monarda herbages. Chemotype was determined by cluster analysis of extracted essential oils. Values represented by bars are least square means \pm SD. For each measured variable, bars with the same letter are not significantly different according to an $F$-protected least significant difference at $P=0.05$. albicans where low activity was correlated with low solubility (9). All compounds with an $\mathrm{EC}_{50}$ value of less than $100 \mu$ moles/dish, except bornyl acetate, contain only one ring (carvacrol, thymol, and $\alpha$-terpineol) or are linear (1-octen-3-ol and linalool ). These results are consistent with the need for both a hydroxyl group and a system of delocalized electrons for antibacterial and antifungal activity $(2,9,20,34,35)$. Isomeric phenolic monoterpenes (thymol and carvacrol), thymoquinone, $\rho$-cymene and $\gamma$-terpinene are common components of mint oils. Both $\rho$-cymene and $\gamma$-terpinene are biosynthetic precursors to thymol and carvacrol $(28,31)$. Thymoquinone is assumed to be a product of oxidation of thymol and/or carvacrol; this reaction occurs under laboratory conditions $(10,19,20)$, but a biosynthetic pathway has not been reported. With the exception of 'Mohawk', herbages with high thymoquinone had high concentrations of thymol; although extracts from 'Mohawk' contained low levels of phenolic monoterpenes, extracts contained a high concentration of their biosynthetic precursor $\rho$-cymene. In 'Trinity Purple', $\rho$-cymene and $\gamma$-terpinene account for approximately $96 \%$ of the compounds found in

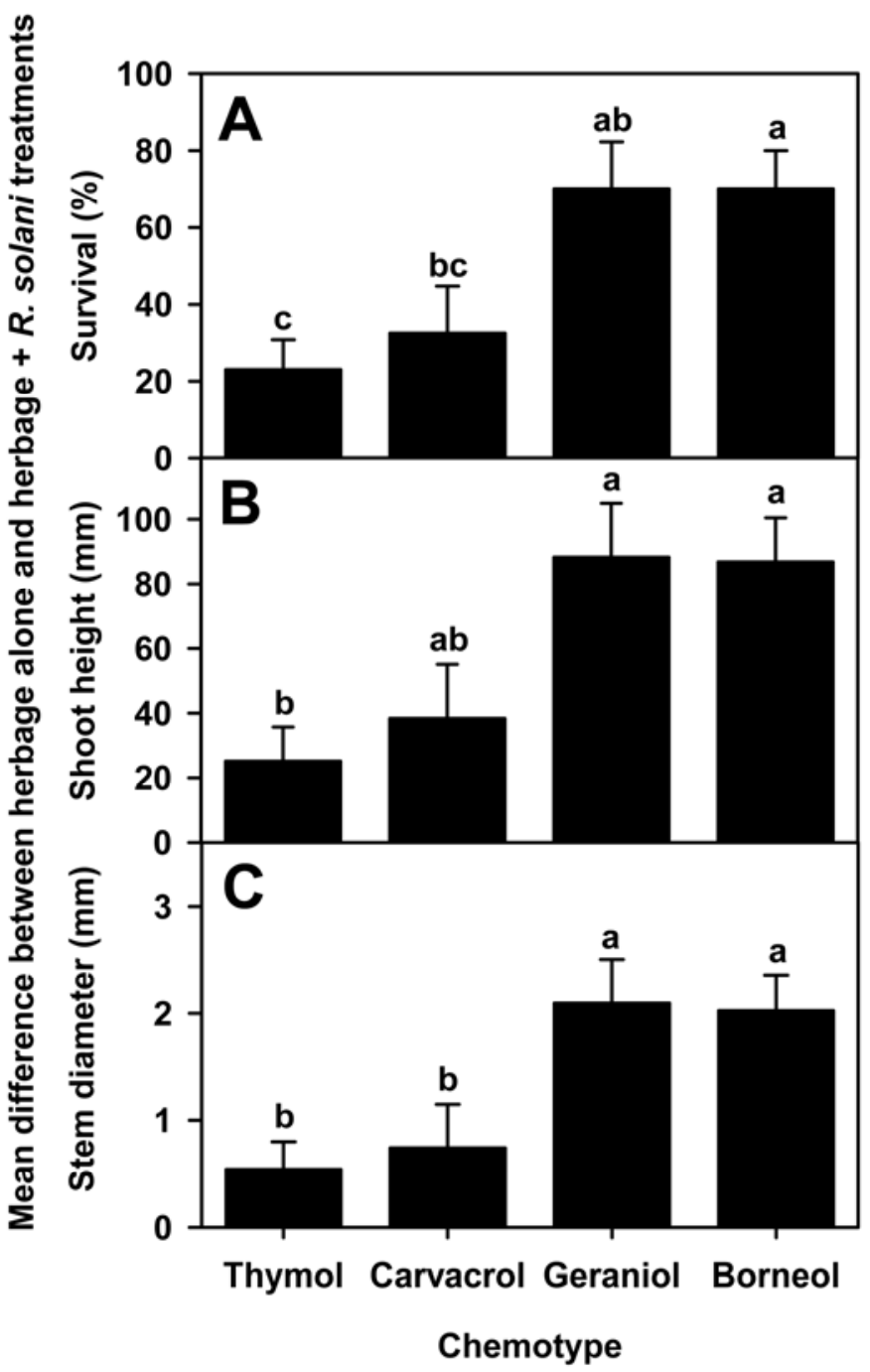

Fig. 5. Herbage chemotype influences on differences in A, plant survival (\%), $\mathbf{B}$, seedling height $(\mathrm{mm})$, and $\mathbf{C}$, stem diameter $(\mathrm{mm})$ in herbage only and herbage + pathogen treatments. Data were collected 8 weeks after planting. Each replicate consisted of two seeds with five replicates for each treatment; experiment was repeated. Seeds were planted in BM-2 or BM-2 amended with one of 13 monarda herbages, both with and without Rhizoctonia solani. Values for herbage + pathogen were subtracted from those of herbage alone for each replicate. Chemotype was determined by cluster analysis of extracted oils. Values represented by bars are least square means \pm SE. For each measured variable, bars with the same letter are not significantly different according to an $F$-protected least significant difference at $P=0.05$. 
the extract; neither phenolic monoterpenes nor thymoquinone were produced indicating a possible truncation of the biosynthetic pathway. Carvacrol and thymol, but not $\rho$-cymene, inhibited seed germination and growth of three weed species (Amaranthus retroflexus, Chenopodium album, and Rumex crispus) (21). In this study, only 'Trinity Purple' inhibited seed germination and reduced shoot height. When analyzed as chemotypes, there was a slight phytotoxic effect of thymol chemotypes on stem diameter. Within the chemotype, herbages that resulted in tomato transplants with the smallest stem diameter and shoot height were highest in thymoquinone, whereas the values for herbages with low thymoquinone more closely resembled the carvacrol chemotypes.

Monarda herbage used in this study had previously been evaluated for control of Pythium myriotylum in tomato (5) and similar herbages had been evaluated for Rhizoctonia damping-off in a preliminary study (12). Only herbage that contained oxygencontaining terpenes controlled Pythium damping-off, but the relationship between chemotypes was not as clear as for Rhizoctonia damping-off. Herbages from 'Croftway Pink' (thymol chemotype), 'Sioux' (a cultivar that has high concentrations of both carvacrol and thymol), and 'Rose Geranium' (geraniol chemotypes) were active against $P$. myriotylum (5), but other herbages with the same chemotype did not control disease. Many monarda herbage selections reduced loss and severity of Rhizoctonia damping-off. The best survival rates in pathogen-infested media were treatments that contained high percentages of thymoquinone and/or phenolic monoterpenes (Fig. 3; Table 2). Survival in treatments with 'Rose Geranium' and 'Rose-scented' herbage differed even though both contained primarily geraniol (88 and $94 \%$, respectively). Since geraniol was a weak inhibitor of $R$. solani in vitro, increased survival in 'Rose Geranium' may have been due to the antifungal activity of the minor components, linalool and 1-octen-3-ol.

Phenolic monoterpenes were highly active against $R$. solani in vitro but may have been available only for a short period of time in a greenhouse environment. At $25^{\circ} \mathrm{C}$, the dissipation half-life of thymol at $25^{\circ} \mathrm{C}$ is 5 days in soil, and 15 days in pond water (16). The half-life of carvacrol should be slightly longer since its vapor pressure is twice that of thymol at $25^{\circ} \mathrm{C}$. Glycosidic bonds play an important role in storage of terpenes in mints, and glycoside breakdown may affect a slow release strategy for some of the terpenes into the greenhouse medium. In a Monarda didyma selection, 1-octen-3-ol was stored as a glycoside, but neither thymol (the primary component) nor borneol were isolated from the glycosidic fraction (29). Although the antifungal activity of thymoquinone against in vitro growth of $R$. solani was low, this compound was the major component of several herbage treatments that provided protection against Rhizoctonia damping-off. If stored as a glycoside, thymoquinone could act as a reservoir for the long-term release of phenolic monoterpenes. When thymoquinone-rich herbage was stored in water under greenhouse conditions, extracts from the water contained a higher percentage of thymol than the original herbage (C. L. Taylor and K. D. Gwinn, unpublished data). Thymoquinone glycosides have been reported for other mints, but not from Monarda spp. $(3,25,33)$. In Origanum glandulosum, carvacrol was the primary oil collected after a 10-min distillation, whereas thymoquinone was the dominant component in oils collected after $3 \mathrm{~h}$. Thymoquinone also dominated the aglycones (83 to $99 \%$ ) recovered after treatment with $\beta$-glycosidase. Based on these data, it has been suggested that thymoquinone exists primarily as a glycosidically bound molecule in $O$. glandulosum (3). In $O$. vulgare sp. hirtum, the essential oils contained only thymol, carvacrol, and 1-octen-3-ol, whereas extraction of the glycosidically bound fraction yielded 14 aglycones with thymoquinone as the dominant compound (40.2\%) (25). Since both Monarda and Origanum are closely related and other members of their taxonomic tribe (e.g., Mentha,
Satureja, Melissa, Thymus, and Salvia) sequester volatiles as glycosides (33), it is likely that thymoquinone is present in 'Puerto Purification', Monarda clinopodia, and 'Mohawk' as a glycoside that is gradually released into greenhouse growing medium. Microbial glycosidase action may release thymoquinone or the environmental conditions in the greenhouse may trigger release of a degradation product (14). Over time, the volatile profile of 'Puerto Purification', Monarda clinopodia, and 'Mohawk' may have been similar to that of 'Mahogany', 'Croftway Pink', or 'Lavender', cultivars that are high in phenolic monoterpenes; percent survival of seedlings in infested media amended with these cultivars did not differ.

Greenhouse growing media amended with several monarda herbages reduced losses and severity of Rhizoctonia damping-off in tomato seedlings. Monarda varieties, in which the phenolic monoterpene biosynthetic pathway is active, provided better control against the pathogen than selections that produced only the precursor molecules or mainly terpenic alcohols. Phenolic monoterpenes and 1-octen-3-ol reduced growth of $R$. solani more than other alcohols. Even though thymoquinone had a high $\mathrm{EC}_{50}$ value, it was a primary component in many herbage selections that were effective against the pathogen in disease assays. In addition, herbages that were relatively high in thymoquinone appeared to have a longer effect on seedling growth and development (K. D. Gwinn and S. E. Greene, unpublished data).

The research reported here presents a novel use of selected bioactive monarda herbages to deliver known antifungal essential oil constituents for control of the damping-off pathogen, $R$. solani in tomato production. Knowledge of the chemistry of monarda herbage as well as sensitivity of pathogen and crop plant to the compounds found in the herbage is needed before this technology is practical in other systems. Although sensitivity of other soilborne pathogens to these oils and herbages differs by pathogen, some monarda herbages were effective against all tested pathogens (e.g., Pythium myriotylum and Sclerotinia sclerotiorum) (5; K. D. Gwinn and S. E. Greene, unpublished data). This technology is most effective in production systems with rapid turnover (e.g., bedding plants and transplants) since most essential oil components of monarda are volatile and degrade rapidly; however, the technology may be expanded by the use of plants that store antifungal compounds such as glycosides and/or more complex compounds (e.g., thymoquinone). Further development of this technology will serve organic or sustainable cropping systems where synthetic pesticide inputs are not desired.

\section{ACKNOWLEDGMENTS}

This project was supported by funding from the University of Tennessee AgResearch, Knoxville, and Berger Peat Moss, Saint-Modeste, Quebec, Canada.

\section{LITERATURE CITED}

1. Angioni, A., Barra, A., Coroneo, V., Dessi, S., and Cabras, P. 2006. Chemical composition, seasonal variability, and antifungal activity of Lavandula stoechas L. ssp. stoechas essential oils from stem/leaves and flowers. J. Agric. Food Chem. 54:4364-4370.

2. Arfa, A. B., Combes, S., Preziosi-Belloy, L., Gontard, N., and Chalier, P. 2006. Antimicrobial activity of carvacrol related to its chemical structure. Lett. Appl. Microbiol. 43:149-154.

3. Belhattab, R., Larous, L., Figueiredo, A. C., Santos, P. A. G., Barroso, J. G., and Pedro, L. G. 2005. Origanum glandulosum Desf. grown wild in Algeria: Essential oil composition and glycosidic bound volatiles. Flavour Frag. J. 20:209-212.

4. Cavanagh, H. M. A. 2007. Antifungal activity of the volatile phase of essential oils: A brief review. Nat. Prod. Commun. 2:1297-1302.

5. Clark, M. M. 2006. Biological control methods for damping-off of tomato seedlings caused by Pythium myriotylum. MS thesis. University of Tennessee, Knoxville.

6. Clark, M. M., Gwinn, K. D., and Ownley, B. H. 2006. Monarda as a biological control method for Pythium myriotylum. (Abstr.) Phyto- 
pathology 96(suppl.):S73

7. Everitt, B. S., Landau, S., and Leese, M. 2001 Cluster Analysis. Oxford University Press Inc., New York.

8. Fraternale, D., Giamperi, L., Bucchini, A., Ricci, D., Epifano, F., Burini, G., and Curini, M. 2006. Chemical composition, antifungal and in vitro antioxidant properties of Monarda didyma L. essential oil. J. Essen. Oil Res. 18:581-585.

9. Griffin, S. G., Wyllie, S. G., Markham, J. L., and Leach, D. N. 1999. The role of structure and molecular properties of terpenoids in determining their antimicrobial activity. Flavour Frag. J. 14:322-332.

10. Güneş, A., Bayraktar, O., and Yilmaz, S. 2006. Liquid-phase oxidation of carvacrol using zeolite-encapsulated metal complexes. Ind. Eng. Chem. Res. 45:54-61.

11. Gupta, M. L., Prasad, A., Ram, M., and Kumar, S. 2002. Effect of the vesicular-arbuscular mycorrhizal (VAM) fungus Glomus fasciculatum on the essential oil yield related characters and nutrient acquisition in the crops of different cultivars of menthol mint (Mentha arvensis) under field conditions. Biores. Technol. 81:77-79.

12. Gwinn, K. D., Greene, S. E., Trently, D. J., Ownley, B. H., and Hamilton, S. L. 2003. Monarda: A new control strategy. Proc. S. Nurs. Assoc. Res. Conf. 48:208-211.

13. Hawke, R. G. 1998. Monarda and powdery mildew resistance. Plant Evaluation Notes, Issue 12. Chicago Botanic Garden, Chicago, IL.

14. Herrmann, A. 2007. Controlled release of volatiles under mild reaction conditions: From nature to everyday products. Angew. Chem. Int. Ed. 46:5836-5863.

15. Hossain, M. A., Ismail, Z., Rahman, A., and Kang, S. C. 2008. Chemical composition and anti-fungal properties of the essential oils and crude extracts of Orthosiphon stamineus Benth. Indus. Crops Prod. 27:328-334.

16. Hu, D., and Coats, J. 2008. Evaluation of the environmental fate of thymol and phenethyl propionate in the laboratory. Pest Manag. Sci. 64:775-779.

17. Inouye, S., Tsuruoka,T., Watanabe, M., Takeo, K., Akao, M., Nishiyama, Y., and Yamaguchi, H. 2000. Inhibitory effect of essential oils on apical growth of Aspergillus fumigatus by vapour contact. Mycoses 43:17-23.

18. Inouye, S., Uchida, K., Takizawa, T., Yamaguchi, H., and Abe, S. 2006. Evaluation of the effect of terpenoid quinones on Trichophyton mentagrophytes by solution and vapor contact. J. Infect. Chemother. 12:100-104.

19. Johnson, H. A., Rogers, L. L., Alkire, M. L., McCloud, T. G., and McLaughlin, J. L. 1998. Bioactive monoterpenes from Monarda fistulosa (Lamiaceae). Nat. Prod. Lett. 11:241-250.

20. Jukić, M., and Miloš, M. 2005. Catalytic oxidation and antioxidant properties of thyme essential oils (Thymus vulgarae L.). Croat. Chem. Acta 78:105-110.

21. Kordali, S., Cakir, A., Ozer, H., Cakmakci, R., Kesdek, M., and Mete, E. 2008. Antifungal, phytotoxic and insecticidal properties of essential oil isolated from Turkish Origanum acutidens and its three components, carvacrol, thymol and p-cymene. Biores. Technol. 99:8788-8795.

22. Lawrence, B. M. 1992. Chemical components of labiatae oils and their exploitation. Pages 399-436 in: Advances in Labiate Science. R. M. Harley and T. Reynolds, eds. Royal Botanic Gardens, Kew.
23. Lawrence, B. M. (ed.) 2006. Mint: The Genus Mentha. CRC Press, Boca Raton, FL.

24. Martínez-Romero, D., Serrano, M., Bailén, G., Guillén, F., Zapata, P. J., Valverde, J. M., Castillo, S., Fuentes, M., and Valero, D. 2008. The use of a natural fungicide as an alternative to preharvest synthetic fungicide treatments to control lettuce deterioration during postharvest storage. Posthar. Biol. Technol. 47:54-60.

25. Milos, M., Mastelic, J., and Jerkovic, I. 2000. Chemical composition and antioxidant effect of glycosidically bound volatile compounds from oregano (Origanum vulgare L. ssp. hirtum). Food Chem. 71:79-83.

26. Mucciarelli, M., Camusso, W., Maffei, M., Panicco, P., and Bicchi, C. 2007. Volatile terpenoids of endophyte-free and infected peppermint (Mentha piperita L.): Chemical partitioning of a symbiosis. Microbiol. Ecol. 54:685-696.

27. Müller-Riebau, F., Berger, B., and Yegen, O. 1995. Chemical composition and fungitoxic properties to phytopathogenic fungi of essential oils of selected aromatic plants growing wild in Turkey. J. Agric. Food Chem. 43:2262-2266

28. Nhu-Trang, T.-T., Casabianca, H., and Grenier-Loustalot, M.-F. 2006. Deuterium/hydrogen ratio analysis of thymol, carvacrol, $\gamma$-terpinene and $p$-cymene in thyme, savory and oregano essential oils by gas chromatography-pyrolysis-isotope ratio mass spectrometry. J. Chromatog. A 1132:219-227.

29. Pfab, I., Heinrich, G., and Francke, W. 1980. Glucoside bound components in the volatile oil of Monarda fistulosa. Biochem. Physiol. Pflanzen. 175:194-207.

30. Pitarokili, D., Tzakou, O., Loukis, A., and Harvala, C. 2003. Volatile metabolites from Salvia fruticosa as antifungal agents in soilborne pathogens. J. Agric. Food Chem. 51:3294-3301.

31. Poulose, A. J., and Croteau, R. 1978. Biosynthesis of aromatic monoterpenes: Conversion of $\gamma$-terpinene to $\rho$-cymene and thymol in Thymus vulgaris L. Arch. Biochem. Biophys. 187:307-314.

32. Rios-Estepa, R., Turner, G. W., Lee, J. M., Croteau, R. B., and Lange, B. M. 2008. A systems biology approach identifies the biochemical mechanisms regulating monoterpenoid essential oil composition in peppermint. Proc. Natl. Acad. Sci. 105:2818-2823.

33. Stahl-Biskup, E., Intert, F., Holthuijzen, J., Stengele, M., and Schulz, G. 1993. Glycosidically bound volatiles-A review 1986-1991. Flavour Frag. J. 8:61-80.

34. Ultee, A., Bennik, M. H., and Moezelaar, R. 2002. The phenolic hydroxyl group of carvacrol is essential for action against the food-borne pathogen, Bacillus cereus. Appl. Environ. Microbiol. 68:1561-1568.

35. Veldhuizen, E. J., Tjeerdsma-van Bokhoven, J. L., Zweijtzer, C., Burt, S. A., and Haagsman, H. P. 2006. Structural requirements for the antimicrobial activity of carvacrol. J. Agric. Food Chem. 54:1874-1879.

36. Ward, J.H. 1963. Hierarchical grouping to optimize an objective function. J. Am. Stat. Assoc. 58:236-244.

37. Wishart, D. 1998. Efficient hierarchical cluster analysis for data mining and knowledge discovery. Comp. Sci. Stat. 30:257-263.

38. Zambonelli, A., D'Aulerio, A. Z., Severi, A., Benvenuti, S., Maggi, L., and Bianchi, A. 2004. Chemical composition and fungicidal activity of commercial oils of Thymus vulgaris L. J. Essen. Oil Res. 16:69-74. 